\title{
The Mediating Role Of Employee Performance: The Effects Of Transformational Leadership, Emotional Intelligence And Role Conflict On Job Satisfaction
}

\author{
Noerhayati Amirullah, ${ }^{2)}$ H. Abdul Rahman Mus, ${ }^{3)}$ Baharuddin Semmaila, ${ }^{4)}$ \\ Roslina Alam \\ 1) Doctoral Student, University of Muslim Indonesia \\ 2, 3,4) Faculty of Economics, University of Muslim Indonesia \\ Corresponding author: Noerhayati Amirullah
}

\begin{abstract}
The purpose of this study is to analyze and explain the effects of transformational leadership, emotional intelligence role conflict on employees performance and job satisfaction in the community health care centers in Makassar. Population in this study that the entire staff working in community health care centers in the city of Makassar, which amounted to 513 officers and scattered or work at 14 community health care centers. Sampling was done by purposive sampling technique with the formulations slovin thus obtained a sample of 225 employees, results of data analysis structural equation modeling using AMOS (Analysis of Moment Structures) software provides evidence that the transformational leadership, emotional intelligence and role conflict significant effect on employees performance, transformational leadership and employees performance significant effect on job satisfaction, emotional intelligence and role conflict is not significant on job satisfaction. Then the last causality provides evidence that the mediating role of employee performance is not proved to analyze the effect of transformational leadership, emotional intelligence and role conflict on job satisfaction.
\end{abstract}

Keywords - Emotional intelligence, job satisfaction, performance, role conflict, transformational leadership

Date of Submission: 24-03-2018

Date of acceptance: 08-04-2018

\section{BACKGROUND TO RESEARCH}

The Government of the Republic of Indonesia through the Ministry of Health in carrying out various development activities of health in Indonesia aims to raise awareness, willingness and ability to healthy living for every citizen of Indonesia in order to realize the degree of public health the highest. Representatives of the purpose set out in the vision of health development is to build and create a healthy society and independent justice are implemented with its mission, namely Improving the health of the community through the empowerment of the community, including the private sector and civil society and protect public health by ensuring the availability of health efforts to plenary, equitable, quality and fairness, ensuring the availability and distribution of health resources and establishing governance in the field of good health are one of the institutions of health services in Indonesia who carry the vision and mission of health development is community health care centers, or better known as Puskesmas, In carrying out the duties and functions of community health care centers have a variety of programs that should be spelled out in the various activities carried out in an integrated manner by health workers in it.

Quality of health services in this case is determined primarily by human resources or health personnel. Community health care centers have a wide range of health services needed by the community so that with these circumstances, the community health care centers are required to provide quality health services, it can be done when health employeess have the knowledge, skills and attitudes of professional work for the improved performance of employees is a key factor that must be improved as a manifestation of the performance of health services in accordance with public expectations.

The results of the observations made at the community health care centers in Makassar show that some policies limit employee working in the work until the cause of the low performance of the officers who then influenced the expectations of employees to provide quality health services. Several previous studies have shown that leaders who pay attention to the factors supporting the creation of an employee's performance is believed to be the driving force behind the creation of the high employee performance. In some of the literature found that transformational leadership style, emotional intelligence, conflict is seen as the role and performance of key 
variables that affect the high or low employee satisfaction. Transformational leadership style, emotional intelligence, conflict of roles and performance can determine the match between the expectations and desires of employees in work

Transformational leadership

\section{THEORETICAL BACKGROUND}

Burns (1978), a political scientist, was the first to conceptualize transformational and transactional leadership, while chronicling the traits of world leaders. In 1985, Bass extended Burns's conceptualization by operationalizing transformational leadership. Nowadays transformational leadership is presumed to be comprised of four dimensions or components. The first component is idealized influence and it occurs when leaders emphasize a collective vision and earn respect and trust from employees through their actions. Second, inspirational motivation is when leaders establish high expectations, thus providing challenge and meaning to employee roles and responsibilities. Third, individualized consideration is when leaders provide special attention to each employee's need (especially the need for achievement) by serving as a mentor or coach.

The final component is intellectual stimulation. Under this component leaders encourage rational thought, challenging the status quo, and ultimately creativity and innovation (Bass and Riggio, 2006). A changeoriented leader, who understands society, the drivers of change and the consequences of change for their organization and employees, can take action and let the changes emerge as an organic part of the strategic and operational running of the organization. This type of leader involves the followers and communicates, explains and adapts learning demands to the capacity of each individual to avoid decrease in performance and satisfaction

Transformational leadership, the force used to his subordinate leaders to provide individual attention, intellectual stimulation and the leader who has charisma. Leadership transformation is calling on the moral values of the followers in an effort to increase their awareness of ethical issues (Rorimpandey, 2013). Transformational leadership as a leader who has the power to influence subordinates in certain ways. With the implementation of transformational leadership subordinates will feel trusted, valued, loyal and respect for his leadership. In the end you will inspire to do more than expected (Bass, 1985). Other scholars view explaining Leadership transformissional as leadership styles used by a manager-oriented performance and status beyond reach various target an entirely new organization (O'Leary, 2001).

Emotional intelligence

Control theory proposes that individual goals represent subjectively experienced reference points. These reference points are then compared to current levels of performance outcomes. When an individual's reference points are salient, they devote scarce resources, such as attention and time (Bergeron, 2007). Emotional intelligence refers to the ability of the individual to recognize his feelings and the feelings of others, ability to motivate oneself, and the ability to manage emotions well in ourselves and in relationships with others. Emotional intelligence includes capabilities-the ability of different, but complementary to academic intelligence, the purely cognitive abilities, as measured by intelligence quotient (IQ) (Goleman, 2002).

There are five major aspects that exist in emotional intelligence (Goleman, 2007: 58-59), namely: (1) recognize their own emotions, an ability to recognize feelings when feelings arise (occur). (2) managing emotions, an individual's ability to deal with feelings that can be expressed accurately, so as to achieve a balance in the individual, (3) motivate yourself, is the ability to resist the gratification and control impulses and feelings motivate positive namely passion, passionate, optimistic and self-confident, (4) recognize the emotions of others is also called empathy, the ability to withstand social cues hidden that suggests what is needed or wanted others so that individuals are more able to accept other points of view, (5) building relationships, are the skills that support the popularity, leadership and interpersonal success. In the context of the work, emotional intelligence is the ability to know what we and others feel, including the proper way to handle the problem. Others are intended to cover the employer, co-workers, subordinates or customers (Martin, 2003). Reality shows that individuals are often unable to deal with emotional problems at work satisfactorily. Not only understand their own feelings, but also the feelings of others who interact with him. The result is often a misunderstanding and conflict between individuals.

\section{Role conflict}

Role conflict refers to the competing demands of different roles assigned to an individual (Kahn et al. 1964). We employ the tenets of control theory namely goal orientation and resource allocation - to argue that sales-service ambidexterity will positively impact role conflict. These salespeople feel the pressure of a duality of expectations. Specifically, the ambidextrous salesperson must navigate both sides of the marketing exchange (i.e. revenue generation and service quality), and the corresponding objectives may seem incongruent. We argue 
that this perception of incongruity may cause the employee to experience role conflict (Carver and Scheier, 1982).

A person will experience conflict peranjika it has two or more roles that are happening at the same time (Luthans, 2006). Role conflict is the conflict because someone expands over a conflicting role. Role conflict is a psychological symptom experienced by someone that could cause discomfort and potentially can reduce the motivation to work, lowering the overall performance (Winardi, 2003). Conflicts arise because of mismatches role expectations communicated in individuals with other people within the organization and outside the organization (Tsai and Shih, 2005; Fanani et al., 2008).

\section{Employee Performance}

Organ (1988) believed that when the definition of job performance expanded to include behaviors such as organizational citizenship (the extent to which one's voluntary support contributes to the success of an organization) the relationship between satisfaction and performance will improve. Performance is basically what is done or not done by employees. Employee performance can affect how much employees contribute to the company such as quantity, output, quality of output, attendance at work and cooperative attitude (Mathis and Jackson, 2006).

Performance is a function of the interaction of individual motivation, skills, and perception of the role (Stoner, 1978, in Tika, 2006). It can be concluded that the performance is a result of job function or activity of a person or group in an organization that is affected by a variety of factors to achieve organizational goals in a given time period. Job function or activity in question is the implementation of the work or activities of a person or group under the authority and responsibility within an organization (Tika, 2006).

\section{Job Satisfaction}

Spector PE (1997) explained job satisfaction as the way people feel about their work and its various bearings. It implies the extent of satisfaction or dissatisfaction in (degree to which people like or dislike) their job. It is definitely a perspective or attitudinal variable. Job satisfaction can be viewed as a global feeling with regard to job or even as a related forecast of attitudes about different aspects of job. This global and facet outlook can be utilized to get a complete depiction of employees' job satisfaction. In average individual satisfaction dengan overall feel of their work, the work itself, and with pengawas serta their colleagues.

However, they tend to Tida satisfied with the fee or salary and promotion opportunities provided by the company (Robbins and Judge, 2008). Job satisfaction refers to an individual's attitude in general toward his work. Important factors that bring more job satisfaction is work for the mental challenge, the appreciation it deserves, an advocate. Officials tend to prefer jobs that give them opportunities to use their skills and abilities and give tasks vary, freedom, and feedback to assess how well the employee works (Robbins, 2008). Other scholars view, explaining that job satisfaction is an effective or emotional response to various aspects of the work. This definition means that one can be quite satisfied with one or more other aspects.

According to self-determination theory, autonomy and self-perceived competence are fundamental universal psychological needs that are important for motivation and psychological well-being. The theory postulates that satisfaction of these basic needs nourishes intrinsic motivation; people need to feel competent and autonomous to maintain their intrinsic motivation (Deci and Ryan, 2000 ; Gagne and Deci, 2005)

Five models of job satisfaction of the following would classify the cause (Breitner and Kinicki, 2008), namely: (1) meet the requirements, a model that explains that satisfaction is determined by the characteristics of a job allows individuals to meet their needs, (2) does not match, is a model that explains that job satisfaction is the result of expectations met. Hope filled represents the difference between what is expected of an individual from a job, such as good wages and promotion opportunities are good, and what in fact received by the employee, (3) the value, a model that explains that satisfaction comes from the perception that a work permit in order to meet the values the important work of an individual, (4) equation, a model that explains that satisfaction is a function of how an individual is treated fairly in the workplace, and (5) the character, looking at job satisfaction as a function of a personal nature and genetic factors. This model shows that a stable individual differences are equally important in explaining job satisfaction and work environment characteristics.

\section{METHODS}

The study was conducted on community health care centers (Puskesmas) in Makassar. Population in this study that the entire employee who is working in community health care centers in the city of Makassar, which amounted to 513 officers and scattered or work at 14 community health care centers. Sampling was done by purposive sampling technique with the help of slovin formulation so obtained a sample of 225 employees who comprise the management, administration officers, nurses and midwives. Hypothesis testing is done by structural equation modeling using AMOS (Analysis of Moment Structures) software 


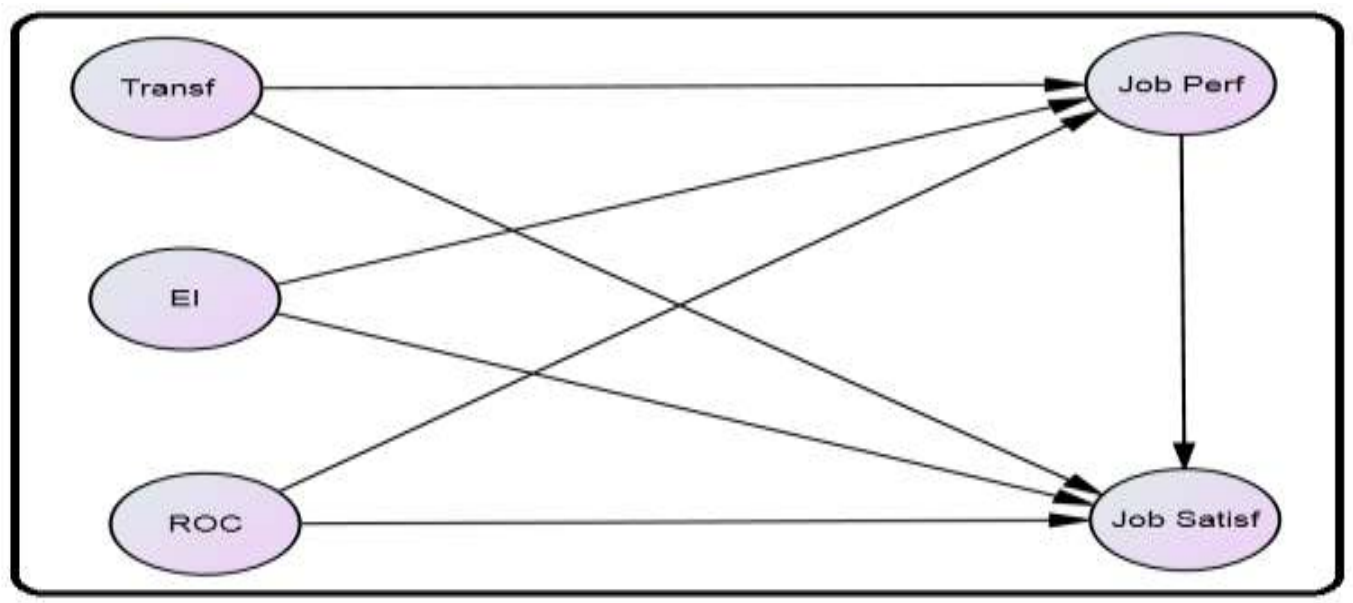

Figure 1 Research model

\section{RESULTS}

Based on scientific research model proposed in this study can be tested against the hypothesis raised by the coefficient test strip on structural equation model. Table 1 is testing the hypothesis by looking at the p-value, if rated $\mathrm{p}$-value $<0.05$ indicated significant effect between the variables. It also describes the direct effect means that there is a positive influence directly between variables and the indirect effect means that there is significant influence indirectly between variables, and the total effect the collection of direct influence and indirect. Test results are presented in Table 1 below:

Table 1. Hypothesis testing

\begin{tabular}{|c|c|c|c|c|c|}
\hline \multirow{3}{*}{ Independent Variables } & \multirow{3}{*}{$\begin{array}{l}\text { Mediating } \\
\text { variables }\end{array}$} & \multirow{3}{*}{$\begin{array}{l}\text { Dependent } \\
\text { variables }\end{array}$} & \multicolumn{3}{|c|}{ Path coefficients } \\
\hline & & & \multicolumn{3}{|c|}{ (direct and indirect effects) } \\
\hline & & & Standardized & $\mathrm{p}<0.05$ & annotation \\
\hline Transf. leadership $\left(\mathrm{X}_{1}\right)$ & - & Em. perf. $\left(\mathrm{Y}_{1}\right)$ & 0,272 & 0,042 & Significant \\
\hline Transf. leadership $\left(\mathrm{X}_{1}\right)$ & - & Job satis. $\left(\mathrm{Y}_{2}\right)$ & 0,314 & 0,047 & Significant \\
\hline Em. intelligence $\left(\mathrm{X}_{2}\right)$ & - & Em. perf. $\left(\mathrm{Y}_{1}\right)$ & 0,234 & 0,049 & Significant \\
\hline Em. intelligence $\left(\mathrm{X}_{2}\right)$ & - & Job satis. $\left(\mathrm{Y}_{2}\right)$ & 0,022 & 0,878 & Non Significant \\
\hline Role conflict $\left(\mathrm{X}_{3}\right)$ & - & Em. perf. $\left(\mathrm{Y}_{1}\right)$ & 0,395 & 0,009 & Significant \\
\hline Role conflict $\left(\mathrm{X}_{3}\right)$ & - & Job satis. $\left(\mathrm{Y}_{2}\right)$ & 0,072 & 0,707 & Non Significant \\
\hline Em. perf. $\left(\mathrm{Y}_{1}\right)$ & - & Job satis. $\left(\mathrm{Y}_{2}\right)$ & 0,57 & 0,034 & Significant \\
\hline Transf. leadership $\left(\mathrm{X}_{1}\right)$ & Em. perf. $\left(\mathrm{Y}_{1}\right)$ & Job satis. $\left(\mathrm{Y}_{2}\right)$ & 0,155 & 0,137 & Non Significant \\
\hline Em. intelligence $\left(\mathrm{X}_{2}\right)$ & Em. perf. $\left(\mathrm{Y}_{1}\right)$ & Job satis. $\left(\mathrm{Y}_{2}\right)$ & 0,133 & 0,15 & Non Significant \\
\hline Role conflict $\left(\mathrm{X}_{3}\right)$ & Em. perf. $\left(\mathrm{Y}_{1}\right)$ & Job satis. $\left(\mathrm{Y}_{2}\right)$ & 0,225 & 0,099 & Non Significant \\
\hline
\end{tabular}

Transformational leadership effect on employee performance

Path coefficient effect of transformational leadership style on employee performance is positive with $0,042 \mathrm{p}$-value $<0.05$. The results of this study prove that transformational leadership shown leadership in working proven to improve employee performance. The situation is caused because the leadership in performing its functions earned the trust, admiration, loyalty and respect from members of the organization and management are always trying to motivate subordinates and give attention to the organization's members. Leaders can always fix the problem and show a visionary attitude in working up a real impact on improving employee performance

Transformational leadership effect on employee job satisfaction

Transformational leadership effect on employee job satisfaction is positive, describing the leader in the performance of its functions have the ability to steer, offers, participation and distribute power will provide a noticeable effect on employee satisfaction, High employee job satisfaction is determined by the influence of the idealistic, inspirational motivation, intellectual stimulation and individualized consideration. The results showed that transformational leadership style characterized by indicators of influence and idealistic individuals who demonstrated leadership preamble proven to improve employee job satisfaction, with a p-value $0.047<0.05$. 
Emotional intelligence effect on employee performance

Emotional intelligence has a positive and significant effect on employee performance. This is evidenced by the route marked positive coefficient. The results of this study provide evidence that the higher the emotional intelligence shown by officers proven to improve employee performance with a p-value of $0.049<0.05$. This situation is caused because the employee has intuitive abilities, interpersonal sensitivity, emotional selfmotivation and determination in carrying out its duties and functions in the work.

Emotional intelligence effect on employee job satisfaction

Emotional intelligence is a positive and significant effect on employee job satisfaction with p-value $0.878>0.05$. This fact explains that employees have high emotional intelligence, but in practice has not been able to increase the sense of satisfaction that appears in official work. Emotional intelligence officials had established at this time with self-awareness, emotional strength, motivation, interpersonal sensitivity, influence and intuition and careful attitude in work appeared in the execution officer has not been able to determine job satisfaction felt by employees. This is because the intelligence employee proved to be able to encourage the officer's like their job, the fit between the expectations of employees with compensation they receive, the desire to always receive colleague, career opportunities wider and treatment monitoring leaders

Role conflict effect on employee performance

The ability of officials in managing role conflict as indicated by the ability of employees to perform activities differently, working with two or more groups differently, accept assignments with limited resources amount, visiting patients not according to the rules defined, receive assignments that are not relevant to the skills owned, must work under the direction of the less obvious, and work not in accordance with the guidelines work in practice proven to improve employee performance with a p-value $0.009<0.05$. These results show that the employee has the ability to manage conflict role so well that it can contribute in the creation of high-performance employees. Constructs important to note the role of officials in managing conflict is shown on the indicator as a result of the assignment and a great responsibility to do officials at the same time.

Role conflict effect on employee job satisfaction

Employees have the ability to manage conflict role, this is evidenced by the p-value $0.707>0.05$ but was unable to increase the sense of satisfaction felt by employees in work. This situation is caused because the employee has the ability to perform activities that are varied, working with several working groups have different orientations, ready to accept assignments with limited resources, visiting patients outside of the terms, accept assignments that do not correspond with the skills of their work, working under the direction of the less obvious, do not work according to the guidelines in force but the overall situation is not able to create employee satisfaction at work.

Employee performance effect on job satisfaction

The creation of the work of employees is evidenced by the ability of employees to produce quality work, the ability of officials to resolve a number of jobs, the knowledge of the employees, the ability of employees to make adjustments work, reliability in work and good relationships between employees and supervisors and safety officers proven to provide a significant contribution the creation of job satisfaction that is felt by the p-value $0.034<0.05$. Such a decision could increase the sense of satisfaction in itself proved to the satisfaction officials officers on their work, the appropriate payment, colleagues who support the promotion, and the satisfaction of the inspection leader.

Transformational leadership effect on employee job satisfaction: The mediating role of employee performance

Transformational leadership but not significant positive effect on job satisfaction through employee performance with a p-value $0.137>0.05$. These results prove the employees performance are not able to play it's a mediating role in explaining the effect transformational leadership on job satisfaction. Employee performance it's only able to contribute directly, so with the relevance between transformational leadership and employee performance as well as the perceived employee job satisfaction.

Emotional intelligence effect on employee job satisfaction: The mediating role of employee performance

Emotional intelligence is positive but not significant effect on job satisfaction through employee performance with a p-value $0.150>0.05$. These results prove the employees performance are not able to play it's a mediating role in explaining the effect of emotional intelligence on job satisfaction. Employee performance 
only able to contribute directly so with relevance between emotional intelligence on the performance, and emotional intelligence is not able to increase the perceived employee job satisfaction.

Role conflict effect on employee job satisfaction: The mediating role of employee performance

A role conflict is positive but not significant effect on job satisfaction through employee performance with a p-value $0.099>0.05$. These results prove the employee performance is not able to play it's a mediating role in explaining the effect of role conflict on job satisfaction. Employee performance only able to contribute directly so with relevance between the roles conflicting of the employee performance, but not on the perceived employee job satisfaction. It is clear that despite the roles conflicting or have duties double, a permanent employee to run specifically well, but because of workload that the high and even tended to execution of the work was not optimal due to the severity of the workload of employees that result in low job satisfaction felt by employees.

\section{CONCLUSION}

Contribution of the most important in the creation of transformational leadership is reflected in the ability of the leader to be Able to provide idealized influence quality of transformational leaders is inspiring for followers and creates values and valuable concepts in individuals and the leader understands followers' need to grow and to satisfy this need and nurturing individuals, will apply coaching style (individual consideration) until the situation is the creation of employee performance and job satisfaction felt by employees increases. Emotional intelligence officer who settles proven to improve employee performance but not on perceived job satisfaction of employees.

The condition is Generally the caused due to employees emotional intelligence have in the context of self-motivation and interpersonal sensitivity, while on the other elements of creation, that is, self-awareness, emotional strength, intuition and influence a precaution, employees have limitations on such elements. The effect of role conflict on employee performance but not for perceived of employees job satisfaction. This situation is the caused, the employee has the ability to manage Reviews their assignment even with limited resources and support tasks that are not compatible with finesse. Contribution officer limited role in managing conflicts, as evidenced by the low ability of employees to work closely with other working groups within and outside the organization and the inability of employees to work with or without the consent directives management and employees to follow the guidelines.

Employees are Able to produce quality work in a solution even with high workload but proved employees to Increase the sense of satisfaction of employees in work. Employees performance are not Able to demonstrate its role as a mediating variable in explaining the effect of transformational leadership, emotional intelligence and conflict role towards the creation of perceived job satisfaction of employees. This study suggests the importance of the dimension of idealized influence to show leadership in transforming the expectations of employees.

The importance of preference scale for to manage the employee emotional intelligence (i.e. selfmotivation, interpersonal sensitivity and intuition). Conflict can work minimized by giving full attention to the assignment of employees with limited resources and fit between skills and tasks assigned employees. The creation of employee performance can be done by paying close attention to the quality and quantity of employees. Future studies may benefit from a longitudinal research design. One, however, must recognize that collecting data from a large number of organizations is problematic. Finally this study reported good reliability and evidence of validity; it would be useful to conduct a study which compare results of this study with those used other acceptable measures of emotional intelligence

\section{REFERENCES}

[1]. Alam, R., and Thoyib, A. (2010). Effect of Empowerment on Job Burnout and Emotional Intelligence Nurses and Midwives in Hospital Palopo and Bone Pare Pare in South Sulawesi. Application Management Journal, 8 (1).

[2]. Bass, BM (1985). Leadership and performance beyond expectations. New York, NY: The Free Press

[3]. Bass, BM, and Riggio, RE (2006). Transformational leadership. Mahwah, NJ: Lawrence Erlbaum

[4]. Bergeron, Diane M. (2007). The Potential Paradox of Organizational Citizenship Behavior: Good Citizens at What Cost?" Academy of Management Review 32 (4): 1078-1095.

[5]. Burns, JM (1978). Leadership. New York, NY: Harper \& Row

[6]. Carver, CS, and Scheier, MF (1982). Control theory: A useful conceptual framework for personality-social, clinical, and health psychology. Psychological bulletin,92 (1), 111-135.

[7]. Deci, E. L., and Ryan, R. M. (2000). The" what" and" why" of goal pursuits: Human needs and the self-determination of behavior. Psychological inquiry, 11(4), 227-268.

[8]. Fanani, Z. Rheny Afriani Hanif and Bambang Subroto. (2008). Effect of Audit Structure, Role Conflict and Role Ambiguity Performance Against Auditor. Journal of Accounting and Finance Indonesia, 5 (2).

[9]. Ferdinand, Augusty. (2006). Management Research Methods, Guidelines for Writing Research Theses and Dissertations Management Sciences. The second edition, Publisher Agency Diponegoro University, Semarang. 
[10]. Gagné, M., and Deci, E. L. (2005). Self-determination theory and work motivation. Journal of Organizational behavior, 26(4), 331-362.

[11]. Goleman, Daniel. (2002). Emotional Intelligence (EQ). T. Heryana interpreter, mold tenth General Gramedia Pustaka, Jakarta.

[12]. Goleman, Daniel. (2007). Emotional Intelligence. Jakarta: PT. Gramedia Pustaka Utama.

[13]. Kahn,RL, Wolfe, DM, Quinn, R., Snoek, JD, and Rosenthal, RA (1964). Organizational stress. NewYork:Wiley,

[14]. Kreitner, Robert and Kinicki. (2008). Organizational Behavior. 8th Edition Boston: McGraw-Hill.

[15]. Mathis, RL and JH Jackson. (2006). Human Resource Management: Human Resource Management. Angelia Dian translation. Jakarta: Salemba Empat.

[16]. Organ, DW (1988). A restatement of the satisfaction-performance hypothesis. Journal of Management, 14 (4), 547-557.

[17]. Robbins, Stephen. P. (2007). Organizational Behavior. Publisher PT. Index. Edition 10.

[18]. Rorimpandey, L. (2013). Transformational Leadership Style, Transactional, Situational Service and Authentic on Employee Performance Bunaken village in the district of the city of Manado. EMBA Journal: Journal of Economic Research, Management, Business and Accounting, 1 (4).

[19]. Sekaran, Uma. (2003). Research Methods for Business: A Skill Building Approach.John Wiley \& Sons, Inc., Fourth Edition.United States of America.

[20]. Spector, P. E. (1997). Job satisfaction: Application, assessment, causes, and consequences (Vol. 3). Sage publications.

[21]. Tika, P. (2006). Organizational Culture and Performance Improvement Company. PT. Earth Literacy. Jakarta.

[22]. Tsai, MT, and Shih, CM. (2005). The influences of organizational and personal ethics on role conflict among marketing managers: An empirical investigation. International Journal of Management, 22 (1), 54.

[23]. Winardi. (2003). Entrepreneur \& Entrepreneurship. Kencana Prenada Media Group.

Noerhayati Amirullah " The Mediating Role Of Employee Performance: The Effects Of Transformational Leadership, Emotional Intelligence And Role Conflict On Job Satisfaction." The International Journal of Engineering and Science (IJES) 7.4 (2018): 45-51 